\title{
Artist-Writers: From Abstract-Expressionist Hostility to 1960s Canonicity
}

\section{Leanne Carroll}

Volume 38, numéro 1, 2013

\section{URI : https://id.erudit.org/iderudit/1066663ar}

DOI : https://doi.org/10.7202/1066663ar

\section{Aller au sommaire du numéro}

\section{Éditeur(s)}

UAAC-AAUC (University Art Association of Canada | Association d'art des universités du Canada)

\section{ISSN}

0315-9906 (imprimé)

1918-4778 (numérique)

\section{Découvrir la revue}

\section{Citer cet article}

Carroll, L. (2013). Artist-Writers: From Abstract-Expressionist Hostility to 1960s Canonicity. RACAR : Revue d'art canadienne / Canadian Art Review, 38(1), 45-54. https://doi.org/10.7202/1066663ar

\section{Résumé de l'article}

Retraçant la réception des artistes-écrivains de la génération des expressionnistes abstraits et de celle de la génération minimaliste et les mettant en contraste, l'auteur évalue les conditions qui ont motivé un changement du statut des écrits d'artistes ; cette activité, qui avait d'abord été perçue comme une forme d'anomalie, allait en effet devenir une pratique tout à fait légitime et même instrumentale au succès de l'artiste. Alors que des artistes-écrivains tels Barnett Newman et Robert Motherwell avaient dû faire face à la méfiance et l'hostilité, Donald Judd a d'emblée été accepté comme un critique. Son essai « Specific Objects », même s'il s’en est défendu, a été lu comme un manifeste pertinent à son art ; il en fut de même de beaucoup d'autres minimalistes qui ont joint à leur pratique d'artistes une activité récurrente de critiques. Les raisons de ce changement sont multiples. Les artistes expressionnistes abstraits étaient reconnus pour avoir pratiqué une peinture instinctive, à laquelle s'opposait l'écriture, identifiée à un intellectualisme dont se méfiait la mentalité du temps. Mais si les valeurs idéologiques associées à la représentation de l'artiste en primitif convenaient à la société de l'après-guerre, les années 1960 allaient connaître une forme différente de cooptation liée en partie au succès des générations expressionnistes précédentes. Se dessine alors un nouveau modèle de l'artiste en professionnel, une figure hautement médiatisée, qui a appris à gérer sa carrière. Pendant que des développements dans la conception et dans la distribution de la presse artistique ouvrent des débouchés à la contribution écrite des artistes et qu'augmente l'intérêt de l'histoire de l'art pour la production contemporaine, le tournant linguistique qui marque la pensée critique du temps favorise un dialogue serré entre les arts visuels et l'écrit.
Tous droits réservés @ UAAC-AAUC (University Art Association of Canada | Association d'art des universités du Canada), 2013
Ce document est protégé par la loi sur le droit d'auteur. L'utilisation des services d'Érudit (y compris la reproduction) est assujettie à sa politique d'utilisation que vous pouvez consulter en ligne.

https://apropos.erudit.org/fr/usagers/politique-dutilisation/ 


\title{
Artist-Writers: From Abstract-Expressionist Hostility to 1960s Canonicity
}

\author{
Leanne Carroll, University of Toronto
}

\begin{abstract}
Résumé
Retraçant la réception des artistes-écrivains de la génération des expressionnistes abstraits et de celle de la génération minimaliste et les mettant en contraste, l'auteur évalue les conditions qui ont motivé un changement du statut des écrits d'artistes ; cette activité, qui avait d'abord été perçue comme une forme d'anomalie, allait en effet devenir une pratique tout à fait légitime et même instrumentale au succès de l'artiste. Alors que des artistes-écrivains tels Barnett Newman et Robert Motherwell avaient dû faire face à la méfiance et l'hostilité, Donald Judd a d'emblée été accepté comme un critique. Son essai « Specific Objects », même s'il s'en est défendu, a été lu comme un manifeste pertinent à son art ; il en fut de même de beaucoup d'autres minimalistes qui ont joint à leur pratique d'artistes une activité récurrente de critiques. Les raisons de ce changement sont multiples. Les artistes expressionnistes abstraits étaient reconnus pour avoir pratiqué une peinture instinctive, à laquelle s'opposait l'écriture, identifiée à un intellectualisme dont se méfiait la mentalité du temps. Mais si les valeurs idéologiques associées à la représentation de l'artiste en primitif convenaient à la société de l'après-guerre, les années 1960 allaient connaître une forme différente de cooptation liée en partie au succès des générations expressionnistes précédentes. Se dessine alors un nouveau modèle de l'artiste en professionnel, une figure hautement médiatisée, qui a appris à gérer sa carrière. Pendant que des développements dans la conception et dans la distribution de la presse artistique ouvrent des débouchés à la contribution écrite des artistes et qu'augmente l'intérêt de l'histoire de l'art pour la production contemporaine, le tournant linguistique qui marque la pensée critique du temps favorise un dialogue serré entre les arts visuels et l'écrit.
\end{abstract}

$\mathrm{O}$ ican art is in the attitudes toward writings by artists of the Abstract-Expressionist generation and of the 1960s cohort that followed. Robert Motherwell (1915-91), a young first generation AbEx painter, and Donald Judd (1928-94), a mature Minimalist, died within three years of one another and were about as far apart in age as were Judd and his younger peers who also wrote: Robert Smithson, Dan Graham, and Mel Bochner. Between 1942 and 1965 alone, Motherwell published nearly forty essays and articles on art, not including the customary artist's statement. Yet he resisted having his writings collected. The first collection appeared in 1992, a year after his death. He often told Stephanie Terenzio "that he would have been better off if he had not written a single word about art." And he deemed the fact that he wrote as much as he did "the tragedy of his life."1 Judd's Complete Writings 1959-1975 were published in 1975 by the Press of the Nova Scotia College of Art and Design. "I'm sorry now I stopped writing just when I should have continued. It left the field to Smithson and Morris,"2 Judd lamented. "The artists my age, who are not only of the 60s, incidentally, but of right now, have not written and talked enough, myself included."3

While Motherwell's and Judd's attitudes may not be representative of all artist-writers in their respective generations, their marked differences nevertheless underscore the changing role of artists and of writings by artists. In the case of Motherwell, to be "better off" if he had not "written a single word about art" implies better off in his career as a painter. To have "not written a single word" would be to be closer to someone like Jackson Pollock: to have made statements about art making in interviews but not to have "writ- ten... about art." Judd's lament is also vis-à-vis other artists. He regrets having "left the field to Smithson and Morris." However, Motherwell's writing about art—typically art before his timeunfavourably singled him out, whereas Judd's writing about art-reviewing current exhibitions for Arts Magazine and Art International and synthesizing his position on the year's trends for Arts Yearbook — favourably allowed him to occupy a field.

Here I chronicle and contrast the reception of the AbstractExpressionist generation of artist-writers with that of the 1960 s generation and assess conditions that constituted the beginnings of a shift from artist writings as ostensible aberration to artist writings as practice. Toward the end of the twentieth century and today, to be an artist-subject is to situate, to identify trends, to use theory. This essay uncovers for the first time the history of what is today generally accepted in the art world, that artists are also artist-writers.

\section{From a Johnny-come-lately to a Critic-Sculptor}

Artists-writers of the 1960s admired certain AbEx predecessors. Judd revered and frequently visited Barnett Newman, ${ }^{4}$ but the most widely celebrated AbEx-generation artist-writer, at least among 1960s artists, was Ad Reinhardt. Barbara Rose marvelled at this New York art-world veteran's sudden popularity among the younger artists in her 1965 survey article on Minimalism, "ABC Art." Bochner recalled that, for Smithson and him, "the precedent for the artist/writer had already been firmly established by two major practitioners:" Reinhardt and, more prominently, Judd. Reinhardt was a visiting professor at Hunter College while Robert Morris was a Master's student there between 1961 and 1966. Reinhardt, Morris, and Smithson curated the 1966 Dwan Gallery exhibition Ten. 
Smithson, in addition to discussing and illustrating Reinhardt's work in his articles, remained in close contact until Reinhardt's death in August of 1967. One of the pull quotes Reinhardt chose for his 1966 ARTnews review of George Kubler's The Shape of Time, a favourite of both Morris and Smithson, was: "the most valuable critic of contemporary work is another artist engaged in the same game." These associations and chance encounters are noteworthy; however, the negative reception of the AbEx generation of artist-writers certainly would not have made writing an appealing option to 1960 s artists. 5

There is no shortage of reviews that derogatorily mention the Abstract-Expressionist artist-writers' intellectual or philosophical interests or backgrounds in discussions of their paintings, and this is likely the crux of Judd's and Motherwell's divergent sentiments toward writing. Reinhardt was isolated, although, as the self-proclaimed conscience of the art world, it is unlikely that he was troubled by the idea that writing might thwart, or at least stall, his art-world success.

Motherwell's intelligence and education in philosophy are often mentioned in reviews as foils to painting. ${ }^{6} \mathrm{He}$ had an undergraduate philosophy degree from Stanford; did a year of graduate work in aesthetics at Harvard, during which he worked on the journals of Delacroix; and studied for a year at Columbia with Meyer Schapiro, with whom Reinhardt also studied. More visibly, Motherwell was the editor of the Documents of Modern Art series and of the single-issue journals possibilities, with Harold Rosenberg, and Modern Artists in America, with Reinhardt. Implying that Motherwell's academic side was detrimental to his painting, critic Clement Greenberg admonished at the early date of 1944, "Only let him stop watching himself, let him stop thinking instead of painting himself through."7 One 1940s painter apparently protested, "We artists were getting along just fine until Motherwell came along with a sense of history." 8 Probable sources for such a complaint are Motherwell's 1944 Partisan Review essay on early twentieth-century French painters' thoughts on abstraction and a 1951 catalogue preface in which he coined the term "School of New York" and which begins with the assertion "Every intelligent painter carries the whole culture of modern painting in his head."9

Newman had written letters and catalogue forewords for artist friends and published five essays in the magazine The Tiger's Eye before his first solo exhibition at Betty Parsons in 1950. That he was considered first and foremost a theoretician is often cited as the cause of the suspicion and hostility he faced when he began exhibiting. Newman was labelled an intellectual, philosopher, gadfly, homespun aesthetician, and genial theoretician. ${ }^{10}$ The first monographic article devoted to the artist, published at the late date of 1958, is titled "The Philosophic Line of B. Newman." In 1945, Newman did describe himself in a New York-based, Spanish-language journal—for which he wrote three essays—-simply as a "writer and critic of New York art." A letter from Mark Rothko dated the same year indicates that he and Newman contemplated getting Newman hired as the New York Times art critic and compares Rothko's output of paintings to Newman's of chapters. ${ }^{11}$ In 1947, when the New York Times critic Edward Alden Jewell devoted both a Thursday and Sunday article to an exhibition for which Newman wrote the catalogue introduction, and which happened to include his work as well, he quoted Newman at length, thus encouraging the perception of Newman as a writer. One can appreciate how he may have appeared to be a "Johnny-come-lately," as Thomas Hess characterized the sentiments of Newman's peers, 12 an observer strategizing from the sidelines, gathering information before entering the game. In retrospect, statements from a 1944 essay suggest that he gleaned a direction from the painters he discussed or projected onto them the achievements he wished to attain, in any case paving the way, albeit ineffectively as it turned out, for his future production. Newman wrote, "The art of the future will, it seems, be an art that is abstract yet full of feeling, capable of expressing the most abstruse philosophic thought.... These artists are doing what seems impossible, expressing feelings and thoughts with abstract forms and flat space. Here is the art of the future." 13 Of course the fact that Newman's sudden contribution to a field of gestural and action painting was seemingly "one stripe" may not have helped.

If the fact that Newman expressed aims for art in writing before exhibiting paintings was viewed as deeply problematic in the 1940s and 1950s, this was not the case for artists beginning their art and writing practices in the 1960s, even though their career moves appear more strategic than Newman's. Judd began reviewing in 1959 and by 1962 was still making paintings while beginning reliefs and floor objects. He turned down invitations for solo exhibitions for seven years before agreeing to his first, which premiered his Plexiglas work at the Green Gallery from December 1963 to January 1964. When "Specific Objects" was published in 1965, the essay would have indeed seemed to explain and establish the perceptions that guide the three-dimensional work he was beginning to develop. The same sequence describes Newman's and Judd's activities-teaching and the odd contribution of early painting to an exhibition, a sustained writing practice, then mature artwork. Yet this chronology only rarely figures into Judd's reception, with approval as opposed to the suspicion Newman faced, and retrospectively.

There are a number of contextual factors that are important for understanding the reception of Judd's writing. "Specific Objects" was a "Positions and Trends" feature essay in the 1965 edition of Arts Yearbook, an annual, themed publication from Arts Magazine. Judd had written over 600 reviews on over 500 artists by the time "Specific Objects" appeared. He was hired by Arts Magazine in late 1959 when three months of editorial 
restrictions at $A R T$ news earlier that fall prompted him to look to Arts Magazine for writing work. ${ }^{14}$ The points raised in the article come right out of his 1963-65 reviews and articles. ${ }^{15}$ Moreover, his article "Local History" for the previous Arts Yearbook contains a section devoted to a new category of "threedimensional work, approximating objects." In it, he expresses the same reservations about defining movements, identifies the "singleness" of early-1950s painting as a precedent, and discusses twenty-four of the forty-eight "Specific Objects" artists. "Specific Objects" is thus an amplification of a section of "Local History" from Arts Yearbook 1964, themed "New York: The Art World," for Arts Yearbook 1965, themed "Contemporary Sculpture." Whereas "Local History" may have seemed less distinctive in a section on "New York Now: Observations, Reviews, Notes" by fellow Arts Magazine staff critics Vivien Raynor and Sidney Tillim and London correspondent Michael Fried, "Specific Objects" may simply have stood out against Robert Goldwater's discussion of pre-1940s sculpture, Sidney Geist's thoughts on colour in sculpture, and William Seitz's introduction to the yearbook, which, while making similar observations on the new three-dimensional work, is distant and academic in comparison to Judd's more urgent tone.

The most notable of the articles' contextual differences is Judd's status. In the 1964 Arts Yearbook contributors page, Judd was described as "a 'constructivist' painter of the rising generation" who "reviews New York gallery shows regularly for ARTS; he had a one-man exhibition this season at the Green Gallery." More visibly, a January 1965 Newsweek article titled "Vanity Fair: The New York Art Scene" pictured artists such as Noland, Rosenquist, Pollock, de Kooning, Johns, and Rauschenberg working or posing in their studios while Judd's photograph and quotes were included on the final pages in a bottom sidebar with critics Thomas Hess, Harold Rosenberg, Clement Greenberg, and Henry Geldzahler. Yet the 1965 yearbook included Judd in the first main entry, "A Survey of Recent Sculpture: An International Selection of Artists, Reproductions and Biographical Sketches," and the contributors page stated that "Donald Judd's work figured in the United States representation at the 1965 Sao Paulo Bienal. A critic as well as a sculptor, he has written for art publications both in this country and abroad." Judd went from a painter who reviews to a critic-sculptor outlining the characteristics of a new art of which, according to the final "Specific Objects" captioned illustration, "Donald Judd, Untitled 1963," he was a practitioner.

Judd has stated on a number of occasions that "Specific Objects" was not intended as a statement on his work. In 1968, Judd told Lucy Lippard:

Incidentally and to get it down, that "Specific Object" article despite what people think was not meant to be a doctrinaire, or dogmatic, or definitive, or anything article.
LL It wasn't? The tone of it was doctrinaire and definitive. DJ I didn't think so. But people keep using it that way. The magazine wanted something [on] what they called a big bunch of three-dimensional art that's being done and so they asked me to do it since they knew I was doing something like that. And [it's] just really meant to report [on] all of that stuff and all of it was very diverse and really not capable of coming under any heading but an extremely general one. And "Specific Objects," which is my title, and I like, isn't meant to be about my work; it's just meant to be about any of that kind of thing that isn't painting or sculpture. ${ }^{16}$

In 1971, John Coplans asked, "Wasn't that a declaration of your situation?” Judd responded, “I don't know. They just gave me a job of reporting. People talk about it being about my work, a manifesto and things like that; but really, I was earning a living as a writer, and it's a report on three-dimensional art." 17 And by 1989 he claimed: "I was given that essay as a job in 1964: it was not a manifesto." 18

Art historians are often skeptical of such statements. Indeed it was Judd who prompted Rosalind Krauss to trot out the Leo Steinberg line "if you want the truth about a work of art, be sure always to get your data from the horse's mouth, bearing in mind that the artist is the one selling the horse." 19 To be sure, Judd's often short sentences, rarely interrupted by qualifying clauses, indeed make some of his statements stand out as definitive pronouncements. However, while perhaps urgent in tone, "Specific Objects" is full of qualifications as opposed to "doctrinaire and definitive:"

The disinterest in painting and sculpture is a disinterest in doing it again, not in it as it is being done by those who developed the last advanced versions.... Obviously, threedimensional work will not cleanly succeed painting and sculpture. It's not like a movement; anyway, movements no longer work; also, linear history has unraveled somewhat. ${ }^{20}$

It is worth noting, regarding the mercenary angle, that "Specific Objects" was not Judd's only assignment for Arts Yearbook 1965. He also wrote "To Encourage Sculpture: The Howard and Jean Lipman Collection," one of five essays on "The Collector's Role" in contemporary sculpture.

Yet Judd's statements are important not because they are true intentions or untrue damage control but because they demonstrate how it was and was not possible for 1960s audiences to read his writings. While it was possible in the 1960 s to conceive of artist writings as not strictly applicable to the author's practice, they were not perceived in this way. In the reprint of the article for the 1975 Complete Writings, Judd endeavours to change this perception. He adds a note: "The editor, not I, included the photograph of my work." He also buries the strong paragraphs on John Chamberlain and Frank Stella in the 
middle, so that instead of ending with "A painting isn't an image. The shapes, the unity, projection, order and color are specific, aggressive and powerful," he ends on the Oldenburg paragraph, the last sentence of which is a decidedly non-manifestolike, throwaway line reminiscent of his review conclusions: "George Brecht and Robert Morris use real objects and depend on the viewer's knowledge of these objects." 21 That the ideas presented in "Specific Objects" are found in Judd's earlier writing, that Judd's sculptural practice was becoming recognized around the time "Specific Objects" was published, and that Judd took efforts to challenge its manifesto-like reception indicate that writing that could be related to artists' visual practices is what resonated in the mid 1960s.

\section{The Ones Selling the Horse}

In the 1940 s and 1950 s, by contrast, commentators took issue less with what AbEx artist-writers wrote than with the mere fact that they wrote. The label of writer or, worse, intellectual would seem to be the crux of the issue. Anti-Intellectualism in American Life, a 1963 book by Richard Hofstadter, offers a contemporary analysis of the understanding of "intellect" in popular writing and the sources of its denunciation that is relevant to the reception of the AbEx artist-writers. Hofstadter reports that "the man of intellect" is regarded, as was Newman, with "resentment or suspicion" and "may be called unreliable, superfluous, immoral, or subversive." The first in Hofstadter's list of professions and vocations to which intellect is attributed are writer and critic, followed by professor, scientist, editor, journalist, lawyer, and clergyman-the "brief-case-carrying professions." Intellect "evaluates evaluations, and looks for the meanings of situations as a whole." It "examines, ponders, wonders, theorizes, criticizes, imagines." Hofstadter demonstrates that "a set of fictional and wholly abstract antagonisms" is the basis for the downgrading of intellect. It is "somehow inconsistent with warm emotion;" it is mere cleverness and so against solidness of character; it is theoretical and so against practicality; it is distinguished and so against egalitarianism and democracy. The latter antagonism in particular, Hofstadter notes, is raised about education, which is noteworthy regarding Motherwell's resented "sense of history."22

Hofstadter observes that intelligence, by contrast, is celebrated. Intelligence is understood as a practical and task- or discipline-specific "excellence of mind." Thus artists who write could be seen to lack devotion and determination, as having opted for the less difficult route of part-time painter and mere mouthpiece. Intelligence "seeks to grasp, manipulate, re-order, adjust," and "will seize the immediate meaning in a situation and evaluate it." $23 \mathrm{~A}$ tough painting practice consisting of an automatic and unencumbered act of self-expression through an immediate, tactile medium on an engrossingly large format would seem to be conceived in these terms. Abstract-Expressionist urgency, seriousness, and commitment to the arena of paint on canvas is intelligent, not intellectual.

Intelligence also "can be praised as a quality in animals," and one of the sources Hofstadter identifies for antiintellectualism is primitivism and its "persistent preference for the 'wisdom' of intuition, which is deemed to be natural or God-given, over rationality, which is cultivated and artificial."24 Art historian Michael Leja has recognized the primitive, along with the unconscious, as two of the most prominent interests of the New York School, pointing out that these interests had "rich and complex lives and roles" in the national culture and in fact served to secure the artists' place in this culture. Thus, a key concept motivating the painters' visual practices is one of the very sources of the prevalent anti-intellectualism in American culture generally. 25

In addition to anti-intellectualism, capitalist thought required a different kind of artist than an intellectual artist-writer. T.J. Clark has argued that Jackson Pollock, by contrast, signified facets of self-representation including "the wordless, the somatic, the wild, the self-risking, spontaneous, uncontrolled, 'existential," and unconscious in a more stable way than had occurred previously and that clarification of these concepts is what was required for everyday life to be further colonized by capitalism. ${ }^{26}$ And it is precisely with 1960 s audiences that the bohemian, spontaneous artist was championed and his paintings were sold. Further, with its "cultural inferiority complex" assuaged by European acceptance of AbEx, America was primed for an art-world boom in artists, audiences, collectors, prices, galleries, media attention, mid-career retrospectives, and mustsee shows-or openings-complete with television crews and paparazzi. 27 The avant-garde, having been embraced to the point of "dissolution," "disrupt[ion]," disappearance, and "demise,"28 became an impossible position and a model that, as Katy Siegel has demonstrated, "did not really 'take." With the realization that Abstract Expressionism achieved not understanding but "American success," namely "money, publicity, and celebrity," 1960s artists instead "embraced and emulated commercial pursuits, middle-class life, and self-presentation," and collected direct subsidies from the National Endowment of the Arts. ${ }^{29}$

Art-world professionalization and celebrity were received with resentment in 1960s articles by Brian O'Doherty ${ }^{30}$ and interviews by Reinhardt, who explained:

I haven't done any cartoons or satires for a long time because it doesn't seem possible. The art world is no longer satirizable. I suppose there isn't much going on except business, and that's not very funny.... De Kooning is living like Elizabeth Taylor. Everybody wants to know who he's sleeping with, about the house he's building and everything. ${ }^{31}$ 
Allan Kaprow offered a more sustained if ambivalent analysis when he asked in ARTnews, "Should the Artist Be a Man of the World?," while Dan Flavin praised the shift from "neurotic "loner" to "public man," and Smithson regularly listed the art magazines in which he had published and his position as "artist consultant" for the engineering and architectural firm TippettsAbbett-McCarthy-Stratton in biographical notes and on museum forms. 32

The new self-presentation entailed "facility with language" and "opportune moves." 33 While one might assume that such competencies would have struck a public still infatuated with the bohemian, expressive artist as disagreeable, Kaprow explained that this public was also "still afraid of being foolish in its new-found culture, ... hav[ing] its doubts allayed only by a reassuring word from the horse's mouth." 34 Thus the short-lived publication Art Voices (1965-67) offered a recurring segment titled "The Artists Say," Art International started an "Artists on their Art" department in 1968, while Art in America ran "The Artist Speaks" from 1968 through 1970. These venues, combined with Artforum's circulation doubling to nearly 11,000 in 1967 compared to 1963 , and the readily available catalogue and anthology reprints of, for example, Judd's "Specific Objects" and Robert Morris's "Notes on Sculpture," made interviews and writing key to making oneself known in the expanded art world. The maxim "one reproduction in an art magazine is worth two one-man shows," or what Chuck Close called "the Artforum good housekeeping seal of approval" after a 1969, illustrated review of his first group show prompted media attention from the major art magazines, would have been an appealing enough reason to publish. 35 While Judd refrained, Smithson and Morris frequently illustrated their essays - of which Morris wrote five for Artforum between 1966 and 1969-with their own work. This got Smithson's First Mirror Displacement from his essay "Incidents of Mirror-Travel in the Yucatan" on the front cover of the September 1969 Artforum. And Smithson instructed, "Drop the Rembrandt print but print the photos of my artwork" to the secretary at Metro magazine when he sent a revised version of his 1968 essay "The Establishment."36

Writing was also a useful way to ensure that one stood out among artists producing apparently similar works in this newly lucrative art world. Judd's and Morris's identities as writers were also used by catalogue essayists to parse the differences amongst Minimalists. ${ }^{37}$ Commentators soon singled out individual artists as spokesmen for entire movements. 38 Whereas multiple critics might function as respondents or even advocates, when it came to artists, commentators seem to have assumed, first, that they were spokesmen and, second, that one artist-spokesman dominated. Critics also found in artist writings conveniently packaged ideas and quotes for their articles, giving the artists further, secondhand exposure. ${ }^{39}$ It seems Smithson used his own articles as a kind of media kit. He wrote to an interested gallerist, Konrad Fischer, "I have an article coming out in the Sept. ARTFORUM on Earth Projects, that will give you more of an idea as to what I'm up to," and to an interested author, Germano Celant, "see Artforum: Earth Projects Sept. 1968, Passaic Dec. 1967, Air Terminal Site June 1967." And he told an interviewer: "My first interest in earthworks came about by going out into large areas and developing large-scale ground systems, which I called 'Aerial Art.' I have a paper on it." 40

\section{A Critical Mass of Minimalists}

The negative art critical reception of the AbEx artists as writers continued into the 1960s, in spite of the increased presence of writings by younger artists. Reinhardt was more often referred to as a polemicist and satirist than an intellectual, and a connection rather than a tension is regularly perceived between Reinhardt's writing and painting. ${ }^{41}$ However, it was often remarked that Reinhardt was better known for his writings and that these are more interesting than his paintings. In 1963, Rose pointed out that "to what degree his articulateness has obscured the way these paintings actually do operate visually remains to be investigated," and James Monte observed that "he has been in print the last few years with such regularity that one tends to see the paintings through written filters." In 1966, Irving Sandler described the fact that "the rancor of polemic has obscured [the paintings'] extraordinary quality" as "deplorable." 42

In a 1966 review, Dore Ashton referred to Barnett Newman as "a kind of midwife," among other insults, in reference to his presentation of written support for the paintings of others. In 1969, Elizabeth C. Baker observed that Newman's "reputation as a philosopher and polemicist have tended to deflect attention from the specific nature of his art" and that "his various writings have sometimes seemed to supersede his paintings... He himself is somewhat responsible for this, of course- he has supervised his historical standing with unflagging vigilance." Just a year after the artist's death, New York Times art critic John Canaday described MoMA's 1971 Newman retrospective as "the strongest argument I have ever seen in favour of artists keeping their mouths shut entirely." 43

A reviewer of Motherwell's 1965 MoMA retrospective indicated that the artist's writings hindered the reception of his paintings.

Motherwell's strength and variety are something you are not led to expect, either, from his widely publicized articles and lectures on the subject of "modernism;"... Motherwell's forte is not the making of masterpieces, but a very high level of performance. He knows (although heaven knows, he doesn't know how to say it in words) what he is doing. ${ }^{44}$ 
While art historian H.H. Arnason praised Motherwell as the "outstanding instance" of the "new American artist-critichistorian" in the first of two Art International articles devoted to the artist, he included the disclaimer:

\section{Despite his unquestioned contributions to the literature and the teaching of modern art and in fact his prolific activities in these fields, they have never, since he first began to paint seriously, constituted anything more than an avocation, al- most a relief from the concentration of thought and energy which for 25 years have been dedicated to the problems of his own painting. ${ }^{45}$}

In a 1967 critique less of the artist as writer/intellectual and more of the content of his claims, sculptor David Hare accused Motherwell of using his spokesman-historian role to lay claim falsely to innovations, essentially writing himself into art history. In the "Letters" section two issues later, a total of five readers, including Lee Krasner and Barnett Newman, congratulated Hare and ARTnews for publishing the scathing critique, thus testifying to the perceived accuracy of Hare's accusations. It is precisely this affair that may have caused Motherwell to wish he had remained silent. 46

The contemporary reception of 1960s artist writings, publicity potential notwithstanding, cannot be characterized as immediate celebration any more than can that of the AbEx generation. ${ }^{47}$ Significantly, what is prevalent in the contemporary reception of 1960s artist writings is critics noting the phenomenon with neither praise nor denigration. The sheer number of so-called Minimalists who wrote-Judd, Morris, Smithson, Flavin, Bochner, Carl Andre, Sol LeWitt—made it a noteworthy detail to report. 48 While it was still possible in 1967 for critic Max Kozloff to emphasize at a symposium on art criticism that "critics are intellectuals after all, and not artists... the critic is neither a scientist, with his necessary independence from emotion, nor an artist (as I've said), free from the responsibilities of verbal articulation," 49 there came a point at which it would be irresponsible of critics not to identify writing by artists as a trend. The move in the reception of writing by artists is not so much from AbEx hostility to 1960s jollity as from group identity to prompt canonicity: artists who did not provide a quotable position paper did not make it into the group and lacked publicity. As Minimalism historian James Meyer puts it, "the other artists, who wrote far less, could not compete." 50

The New York art world had grown from a community of artists into an industry to be navigated with the aid of art magazines, an expansion largely precipitated by the American-type success achieved by the Abstract Expressionists themselves. Any insights artists provided in published writings served as shortcuts for movement-making critics, curators, and dealers. In a gallery scene that was too large to visit entirely in person, writing by artists mattered. It set one apart.

\section{Temp Work and the Linguistic Turn}

That the technological and economic infrastructures of magazine publishing underwent changes in the late 1960s is not without significance. When advertisers dropped generalinterest magazines in favour of television, causing Saturday Evening Post, Life, and Look to go under in the late 1960s and early 1970s, spates of special-interest magazines had already been filling stands and mailboxes for a decade. Improvements to printing technology had made small print-runs affordable, and specialized content guaranteed just the right audience for specialized products. 51 The new technology may have influenced a salesman for a San Francisco printing firm to come to Philip Leider-then a gallery assistant with no art background-looking for business. The niche ad exposure may have influenced the expansion of ad pages from six in the debut 1962 issue to over forty by 1970 in the resulting publication, Artforum, which, unlike the more comprehensive but hodge-podge ARTnews, offered a setting specifically for the discussion of West Coast and eventually New York contemporary art. Whether to contribute to the advancement of the field or fill the space between ads, Artforum and ARTnews, in addition to Art International and Arts Magazine, needed writing every month. Certainly eager young art critics helped fill the void. According to Amy Newman's 1993-99 interviews with the "Artforum group," critics reported being delighted to be offered the opportunity to write, for example, the "New York Letter" or "London Letter" for Art International while only in their twenties. 52 But artist writings did the job too.

It is not surprising then that most published artist writings were solicited by editors. In the late 1950s editors sent word or placed ads indicating that staff reviewers were needed. Judd raised his hand when his "American Painting from 1940-1950" professor, Meyer Schapiro, asked if anyone might be interested in writing reviews. Thomas Hess at ARTnews was seeking reviewers. Painter Sidney Tillim became an art critic by twice responding to a want ad in Arts Magazine; one editor had fired him in the interim for wearing sneakers to a gallery. He also wrote a book review for the College Art Journal when he found out he got to keep the book; he wanted Michel Seuphor's book on Mondrian. Bochner and Smithson's "The Domain of the Great Bear" was not solicited but they were granted permission to produce it for Art Voices on the condition that they do the layout themselves. At Harper's Bazaar, literary editor and former Parsons Gallery employee Dale McConathy sought to elevate high fashion through bricolage-style juxtaposition with 
obscure reading. To this end, he sought writing from concrete poets, Robert Smithson-whose wife, artist Nancy Holt, worked briefly as McConathy's assistant—Sol LeWitt, and Dan Graham. 53

Leider was not experiencing a staff shortage, as at ARTnews. He was not offering a tryout to those who inquired, as Bochner did at Arts Magazine. And he was not seeking avant-garde prose to add cultural cachet to fashion ads, as at Harper's Bazaar. According to Amy Newman's interviews, Leider envisioned Artforum above all as a forum and solicited writings by artists on an article-by-article basis. While his repeated attempts to entice Judd to publish failed-Judd detested Tillim's and Fried's criticism in Artforum ${ }^{54}$ _Sol LeWitt, one of Smithson's suggestions, obliged with "Paragraphs on Conceptual Art" (June 1967). Leider had asked Smithson for "the names of a few of your colleagues who you feel might have something to contribute" to the renowned June 1967 sculpture issue. 55 Leider recalled of Robert Morris's writing that "he did it himself, on his own initiative. I never knew when it was coming, it just came over the transom." 56 However, influential Artforum contributor Barbara Rose encouraged and had some input into Morris's first "Notes on Sculpture" of February 1966.57

Mercenary motivations are another important condition of production, elaborated most famously by Judd. In his 1974 introduction to his Complete Writings, Judd asserts: "I wrote criticism as a mercenary and would never have written it otherwise." Commentators are skeptical of this statement. By 1989 Judd was only slightly more forthcoming: "For me writing reviews was a part-time job, and I'd always liked writing." Responding to Judd's original statement, Bochner declared in 2005, "I don't believe him. Sure, he had to make a living, but there were a lot easier and more lucrative part-time jobs." Judd would have disagreed. He told Lippard in 1968: "Any little job would have been fine but there weren't any little jobs." Lippard asks, "How come you were never a guard in the museums?"a fair question given that this was how a number of artists, including Robert Ryman, Flavin, and Bochner, earned a living. "Oh, I was a guard in the Army now and then and I hated it.... We had some guard duty. And it's torture." Noting the artistguards and Frank Stella's work as a housepainter, Ann Temkin points out that "writing was a skill at his disposal" and that "there certainly is no reason to doubt" Judd's statement that he wrote as a mercenary. Moreover, Judd's response to Lippard's question "How has the teaching been working out?" is equally mercenary: "I only teach in case of future poverty." It is worth noting that only a decade earlier he described his great financial difficulties in letters to his girlfriend and let Professor Schapiro know he was interested in writing reviews for ARTnews because the private school where he taught shop and world history part time "was getting rid of part-time people so I thought maybe I had better take what I could just in case." Less structured than working as a guard, housepainter, or teacher, writing reviews was as convenient for Judd as for the Artforum critics writing graduate theses:

Since there were no set hours and since I could work at home it was a good part-time job. It took three or four days to see the shows and perhaps a week or so off and on to write the reviews, which I always put off until the deadline.

But he could always use more work. Even during his fourth year as a reviewer at Arts Magazine and his first solo exhibition, Judd inquired about working as a critic for The Washington Post. In interviews from the late 1960s and early 1970s, Judd frequently mentions his need for more money to make more art. 58

While Judd's biographical chronologies state that increasing sales of his art allowed him to stop writing for Arts Magazine, and while editor James Mellow had resigned, because of new ownership, the same month as Judd in March 1965, it is important to note that Judd already had another writing gig when he left. He had been hired by Art International that January to write the "New York Letter." It was not until after his departure from Arts Magazine that he was fired for his "shambling basic-Hemingway" style in a termination letter from Art International editor James Fitzsimmons, dated 21 April 1965 and made famous by Judd's inclusion of a facsimile in his Complete Writings. Nevertheless, by July he had been picked up by dealer Leo Castelli, and two-and-a-half years later he could afford a $\$ 68,000$ five-storey, cast-iron building at 101 Spring Street. Among other motivations, writing criticism in the 1960s was convenient and satisfactorily remunerative temp work for artists.

Writing also figured prominently in 1960s culture generally. The humanities and social sciences underwent a linguistic turn following a new awareness of structural linguistics in France in the 1950s and an interest in Ludwig Wittgenstein's investigations on the use value of language. It is "beyond the bounds of sense even to entertain the idea that a form of art could maintain itself outside a society of language-users," wrote philosopher of art Richard Wollheim in a 1967 book review that Smithson quoted in a draft essay. 59

With the surge in print culture, art was more than ever accessed and mediated through reproductions and text in magazines and books. In 1965, Henry Geldzahler avowed: "Now we no longer have trade routes; we have ARTnews, Harry Abrams, Phaidon, André Malraux, and jet travel-instant international communication. Between them nothing is unavailable." The field of art in 1960s America was discursive-in the ordinary sense, as in proceeding by reasoning-and accessed through discourse - again, as in written debate. It is not surprising then that apart from Leider the entire "Artforum Group" of critics 
began as painters but instead found criticism "an arena in which to act." Similarly the growth of the discipline of art history, especially the art historical study of twentieth-century art, increased the need for documents to consult. Note the 1960s appearance of Robert L. Herbert's Modern Artists on Art: Ten Unabridged Essays, one selection criterion of which was "classroom use and experience," and Herschel B. Chipp, Joshua C. Taylor, and Peter Selz's Theories of Modern Art: A Source Book by Artists and Critics, which, the editors explained, "came into being in response to a need, voiced by art historians and students, for access to the fundamental theoretical documents of twentieth-century art." The expanded art-world machine worked more efficiently when artists provided contemporary documents themselves. Being well versed in art's history and criticism became a prerequisite for art production, for making works that can be "visible" to the art community. Art becomes a supplement to art discourse, and not the other way around. Geldzahler identified "the artist as art historian, as scholar of the history of art" based on the advancements in communication and travel that "multipli[ed] incalculably the amount of visual material that can, and in many cases must, be brought to bear in the intelligent appreciation of contemporary art." In 1962, Robert Morris wrote to Henry Flynt "I think today art is a form of art history."60

Self-presentation based on an American model of "making it" followed AbEx sales and celebrity, and an expanded art world thrived on publicity. The critical mass of artist-writers necessary for trend-reporting was achieved. Smaller print-runs, and thus special-interest magazines, were newly economical. Writing criticism was convenient and satisfactorily remunerative temp work. And art was more than ever accessed as printed reproductions accompanied by written text. These are some of the 1960s conditions that, in contrast to the 1940s and 1950s, influenced and made manifest the valuing of artist writing and that may begin to inform our readings of the writings themselves.

\section{Acknowledgements}

Portions of this article were presented at the Museum of Modern Art, New York in 2011 as part of New Perspectives on Abstract Expressionism: A Young Scholars' Panel. I am thankful to respondents David Anfam, Michael Leja, Katy Siegel, and Ann Temkin for providing the opportunity and helpful feedback. Special thanks to Mark A. Cheetham for his prompt, considered, and valuable responses to my work.
Notes

1 Stephanie Terenzio, preface to Robert Motherwell, The Collected Writings of Robert Motherwell, ed. Stephanie Terenzio (New York, 1992), v-vi.

2 Donald Judd, "A Small Kind of Order: Donald Judd," interview by David Batchelor, Artscribe International 78 (November-December 1989): 66.

3 Donald Judd, "A Long Discussion Not about Master-Pieces but Why There Are So Few of Them, Part II (1984)," in Complete Writings 1975-1986 (Eindhoven, 1987), 76.

4 See David Raskin, Donald Judd (New Haven, CT, 2010), 137n59, 90-91.

5 Barbara Rose, "ABC Art," Art in America 53, 5 (OctoberNovember 1965): 62-65; Mel Bochner, Solar System \& Rest Rooms: Writings and Interviews, 1965-2007 (Cambridge, MA, 2008), 199; Ad Reinhardt, Art-as-Art: The Selected Writings of Ad Reinhardt, ed. Barbara Rose (1st ed., 1975; Berkeley, 1991), 226.

6 See Anonymous, "Review [Robert Motherwell]," ARTnews (November 1944): 26; Paul Bird, "Motherwell: A Profile," Art Digest 26, 1 (1 October 1951): 6; James Fitzsimmons, "Robert Motherwell,” Design Quarterly (Minnesota) 29 (1954): 20.

7 Clement Greenberg, The Collected Essays and Criticism, ed. John O’Brian, 4 vols. (Chicago, 1986), 1:241.

8 Quoted in Terenzio, preface, vi.

9 Robert Motherwell, The Writings of Robert Motherwell, ed. Dore Ashton and Joan Banach (Berkeley, 2007), 40-43, 154.

10 Judith Kaye Reed, "Newman's Flat Areas," Art Digest 24, 9 (1 February 1950): 16; Stuart Preston, "Diverse New Shows," The New York Times (29 April 1951): 2:6; Belle Krasne, "The Bar Vertical on Fields Horizontal," Art Digest 25, 15 (1 May 1951): 16; E.C. Goossen, "The Philosophic Line of B. Newman," ARTnews 57, 4 (Summer 1958): 30; Thomas B. Hess, "Barnett Newman," ARTnews 49, 1 (March 1950): 48; Hess, "Barnett Newman," ARTnews 50, 4 (Summer 1951): 47.

11 See Michael Leja, Reframing Abstract Expressionism: Subjectivity and Painting in the 1940s (New Haven, CT, 1993), 87, 338n63.

12 Thomas B. Hess, Barnett Newman (New York, 1971), 31.

13 Barnett Newman, Barnett Newman: Selected Writings and Interviews, ed. John Philip O’Neill (Berkeley, 1992), 69, 70.

14 Donald Judd and Lucy Lippard, "Donald Judd Interviewed by Lucy R. Lippard, April 10, 1968," in Lucy R. Lippard Papers, 1940s-2006: Box 32 (Washington, DC: Archives of American Art, Smithsonian Institution, 1968), 9-10.

15 See especially Donald Judd, Complete Writings 1959-1975: Gallery Reviews, Book Reviews, Articles, Letters to the Editor, Reports, Statements, Complaints (Halifax, 1975; repr. 2005), January 1963 on Lee Bontecou, 65; February 1963 on Ronald Bladen, 75; MayJune 1963 on Jasper Johns, 89-90; September 1963 on Kenneth Noland, 93; April 1964 on Dan Flavin, 124; February 1965 on 
Robert Morris, 165; April 1965 on Bontecou, 178.

16 Judd and Lippard, “Interview," 38.

17 Donald Judd, "An Interview with Don Judd," interview by John Coplans, Artforum 9, 10 (June 1971): 43-44.

18 Judd, "Small Kind," 62.

19 Rosalind Krauss, "The Material Uncanny," in Donald Judd: Early Fabricated Work (New York, 1998), 11. See also Leo Steinberg, Encounters with Rauschenberg: (A Lavishly Illustrated Lecture) (Houston; Chicago, 2000), 15.

20 Judd, Complete Writings 1959-1975, 181.

21 Judd, Complete Writings 1959-1975, 189, 184, 189.

22 Richard Hofstadter, Anti-Intellectualism in American Life (New York, 1963), 24, 26, 25, 45-46, 51.

23 Hofstadter, Anti-Intellectualism, 25.

24 Hofstadter, Anti-Intellectualism, 25, 48.

25 Leja, Reframing Abstract Expressionism, 6-7; see chap. 2.

26 T.J. Clark, "Jackson Pollock's Abstraction," in Reconstructing Modernism: Art in New York, Paris, and Montreal, 1945-1964, ed. Serge Guilbaut (Cambridge, MA, 1990), 180.

27 See A. Deirdre Robson, Prestige, Profit, and Pleasure: The Market for Modern Art in New York in the 1940s and 1950s (New York, 1995), 262 and James Meyer, Minimalism: Art and Polemics in the Sixties (New Haven, 2001), frontispiece, fig. 2, fig. 3.

28 William Seitz, "The Rise and Dissolution of the Avant-Garde," Vogue 142, 1 (September 1963): 182-83, 230-33; Lawrence Alloway, "Art and the Communication Network," Canadian Art (April 1966): 36; Barbara Rose and Irving Sandler, "Sensibilities of the Sixties," Art in America 55, 1 (January-February 1967): 44; James S. Ackerman, "The Demise of the Avant-Garde: Notes on the Sociology of Recent American Art," L'Arte (March 1969): 5-17.

29 Katy Siegel, Since '45: America and the Making of Contemporary Art (London, 2011), 31, 94, 105.

30 Brian O'Doherty, "The Corruption of Individuality: More Problems for the Artist-Big Business and Synthetic Freedom," The New York Times (23 June 1963): X 15; O’Doherty, "Minus Plato (1966)," in Minimal Art: A Critical Anthology, ed. Gregory Battcock (1st ed., 1968; Berkeley, 1995), 252.

31 Reinhardt, Art-as-Art, 14, 27.

32 Allan Kaprow, "The Artist as a Man of the World ("Should the Artist Be a Man of the World?" [1964])," in Essays on the Blurring of Art and Life, ed. Jeff Kelley (Berkeley, 2003); Dan Flavin, "On an American Artist's Education," Artforum 6, 7 (March 1968): 32; Robert Smithson and Nancy Holt, "Robert Smithson and Nancy Holt Papers, 1905-1987" (Washington, DC: Archives of American Art, Smithsonian Institution, 1986-2005), 3833:238, 3832:982.

33 Thomas E. Crow, The Rise of the Sixties: American and European Art in the Era of Dissent (1st ed., 1996; New Haven, CT, 2004), 164.

34 Kaprow, "The Artist," 55.

35 John A. Walker, "Periodicals since 1945," in The Art Press: Two
Centuries of Art Magazines: Essays Published for the Art Libraries Society on the Occasion of the International Conference on Art Periodicals and the Exhibition The Art Press at the Victoria and Albert Museum, London, ed. Trevor Fawcett and Clive Phillpot (London, 1976), 51; Amy Newman, Challenging Art: Artforum 1962-1974 (New York, 2000), 452-53.

36 Smithson, "Papers," 3834:1146.

37 Barbara Rose, "Post-Cubist Sculpture," in American Sculpture of the Sixties, ed. Maurice Tuchman (Los Angeles, 1967), 39; "The Theorists: Judd and Morris” in Martin Friedman, Barbara Rose, and Christopher Finch, 14 Sculptors: The Industrial Edge (Minneapolis, 1969), 13.

38 See Elizabeth C. Baker, "Judd the Obscure," ARTnews 67 (April 1968): 44; Martin Friedman, "Robert Morris: Polemics and Cubes," Art International 10, 10 (December 1966): 23; Jeanne Siegel, "Robert Smithson," Arts Magazine 41, 3 (December-January 1966-67): 61.

39 See James R. Mellow, "Hostage to the Gallery," The New Leader (14 March 1966): 32-33; Martin Friedman, "The Nart-Art of Donald Judd," Art and Artists (February 1967): 59-61.

40 Smithson, "Papers," 3832:1096, 1105, 1189, 1192; Robert Smithson, Suzaan Boettger, and Willoughby Sharp, "Degrees of Disorder," Art in America 86, 12 (1968 interview; December 1998): 77.

41 See Hilton Kramer, "Ad Reinhardt's Black Humor," The New York Times (27 November 1966): D17; Kramer, "Art," The Nation 196 (22 June 1963): 534; and Priscilla Colt, "Notes on Ad Reinhardt," Art International 8 (October 1964): 34.

42 Barbara Rose, "Americans 1963," Art International 7, 7 (September 1963): 77; James Monte, "Reviews," Artforum 2, 5 (November 1963): 44; Irving Sandler, "Reinhardt: The Purist Backlash," Artforum 5, 4 (December 1966): 41.

43 Dore Ashton, "Art: Barnett Newman and the Making of Instant Legend," Arts and Architecture 83, 5 (June 1966): 4; Elizabeth C. Baker, "Barnett Newman in a New Light," ARTnews 67, 10 (February 1969): 38; John Canaday, "Mike, Elaine, Woody, Mr. Newman, God, and Me," The New York Times (31 October 1971): D21.

44 Betty Kaufman, "Motherwell Retrospective," Commonweal (New York) 83, 12 (24 December 1965): 383.

45 H.H. Arnason, "On Robert Motherwell and His Early Work," Art International 10, 1 (January 1966): 17.

46 David Hare, "Communication," ARTnews 66, 8 (December 1967): 8, 10 .

47 See Bochner, Solar System, xvii; John Perreault, "A Minimal Future? Union Made: Report on a Phenomenon," Arts Magazine 41, 5 (March 1967): 30-31; Perreault, "Nonsites in the News," New York 2, 8 (24 February 1969): 44; Emily Wasserman, "Robert Smithson," Artforum 6, 9 (May 1968): 62.

48 See Battcock, preface, Minimal Art: A Critical Anthology; Annette Michelson, “10 x 10: Concrete Reasonableness," Artforum 5, 5 
(January 1967): 31.

49 Max Kozloff in William C. Seitz, moderator, Art Criticism in the Sixties: A Symposium of the Poses Institute of Fine Arts, Brandelis University, Waltham, Massachusetts, April 1967 (New York, 1967), n.p.

50 Meyer, Minimalism, 166.

51 See David Abrahamson and Carol Polsgrove, "The Right Niche: Consumer Magazines and Advertisers," in The Enduring Book: Print Culture in Postwar America, ed. David Paul Nord, Joan Shelley Rubin, and Michael Schudson (Chapel Hill, 2009), 107-18.

52 Newman, Challenging, Max Kozloff 54, Barbara Rose 60, Michael Fried 73.

53 See James Meyer, "The Mirror of Fashion: Dale Mcconathy and the Neo-Avant-Garde," Artforum 39, 9 (May 2001): 134-38.

54 Philip Leider, "Perfect Unlikeness," Artforum 38, 6 (February 2000): 103.

55 Smithson, "Papers," 3832:947.

56 Newman, Challenging, 236.

57 See Meyer, Minimalism, 155 and Leanne Carroll, "The Artist as Critic: A Parodic Reading of Robert Morris's Writing and Minimalist Sculpture," University of Toronto Art Journal 1 (2008): 7-8, http://jps.library.utoronto.ca/index.php/UTAJ/issue/view/333.

58 Judd, Complete Writings 1959-1975, vii; see Roberta Smith, “Two Critics Collected," Art in America (November-December 1976): 36; Judd, "Small Kind," 66; Bochner, Solar System, 196; Judd and Lippard, "Interview," 14-15; Ann Temkin, "Barnett Newman and Donald Judd: Artist as Polemicist," in The Writings of Donald Judd: A Symposium Hosted by the Chinati Foundation, Marfa, Texas, May 3-4, 2008 (Marfa, TX, 2009), 160; Judd and Lippard, "Interview," 36; Thomas Kellein, "The Whole Space" in Donald Judd: Early Work 1955-1968 (New York, 2002), 18n17; Judd and Lippard, "Interview," 9; Judd, Complete Writings 1959-1975, vii; Kellein, "Whole Space," 34; see Grace Glueck, "A Box Is a Box Is a Box," The New York Times (10 March 1968): D23 and Judd, "Interview, Coplans," 45.

59 Richard Wollheim, "On the Psychology of Art," Art and Artists 2, 5 (August 1967): 19; Smithson, "Papers," 3834:808.

60 Henry Geldzahler, "The Art Audience and the Critic (1965)," in The New Art: A Critical Anthology, ed. Gregory Battcock (New York, 1973), 98; Newman, Challenging, 47, 50, 53, 56, 61, 71, 75; Robert L. Herbert, ed., Modern Artists on Art: Ten Unabridged Essays (Englewood Cliffs, NJ, 1964), vii; Herschel B. Chipp, Joshua C. Taylor, and Peter Selz, eds., Theories of Modern Art: A Source Book by Artists and Critics (Berkeley, 1968), v; Robert Morris, "Letter from Bob Morris to Henry Flynt, Dated 8/13/62," in Down with Art, ed. Henry Flynt (New York, 1968), n.p. 